\title{
MICB Gene
}

National Cancer Institute

\section{Source}

National Cancer Institute. MICB Gene. NCI Thesaurus. Code C104648.

This gene plays a role in activation of the immune cytolytic response. 